KEYWORDS

Trade policy

Economic reform

Exports

Economic growth

Economic analysis

Simulation methods

Mathematical models

Central america

Costa Rica

Honduras

El Salvador

Marco V. Sánchez-Cantillo

Economic Affairs Officer

Development Policy Analysis

Division

Department of Economic and

Social Affairs

United Nations

- sanchez-cantillo@un.org
CEPAL REVIEW 98 A A UUST 2009

\section{Trade policy reform and poverty: \\ successes and failures in Central America}

\author{
Marco V. Sánchez-Cantillo
}

$\mathrm{D}$

uring the past two decades, trade regimes in Latin America have been reformed to facilitate export-led growth, in the expectation that the benefits of this growth would eventually trickle down and thereby help the poor. These goals have been achieved to differing degrees. Their accomplishment has depended not only upon the effectiveness of the trade policy reforms but also upon exchange-rate policy, external shocks and remittance inflows. Technological change has also been crucial when it comes to capitalizing on the benefits of the reforms. These assertions are substantiated using simulation results from a computable general equilibrium model solved with data for Costa Rica, El Salvador and Honduras. The model is combined with a microsimulation methodology to capture the full distributive implications of simulated policy and external shocks. 


\section{I}

\section{Introduction}

After overcoming the debt crisis and stabilizing their economies, most Latin American countries initiated a process of economic reform. Trade policy reforms, consisting chiefly of import liberalization and deliberate export promotion, were implemented most rapidly to exploit comparative advantages in agriculture and some manufacturing sectors. Reforming countries expected to achieve rapid export-led growth that would ultimately translate into a diminution of poverty.

Even though most Latin American countries have opted for fairly similar reforms to their trade regimes, their trajectories with regard to export-led growth and poverty have been divergent in numerous cases. This paper contends that trade policy reforms have met their goals in countries which, firstly, have been able to maintain competitive and relatively stable real exchange rates and, secondly, have become more productive. External shocks, originating from global price fluctuations and massive inflows of capital and workers' remittances, are viewed here as factors that have kept some countries from attaining real exchangerate stability and competitiveness. Furthermore, even though less costly imports and increased inflows of foreign direct investment (FDI) have played an essential role in spurring productivity growth during periods of trade policy reform, these gains have materialized only in countries with relatively abundant skilled labour and diversified and modernized export sectors.

The argument of this paper is substantiated with evidence for three Central American countries, Costa Rica, El Salvador and Honduras. Specifically, this evidence is gathered by associating simulation results from a static computable general equilibrium (CGE) model solved using data for the three countries with actual trends for the period 1990-2003. The CGE analysis is also complemented by a microsimulation methodology implemented using microdata to capture the full distributive implications of simulated policy and external shocks.

The remainder of this paper is structured as follows. The main trade policy reforms undertaken and the socio-economic performance observed in the three countries under consideration during the 1990-2003 period are described in section 2 . The analytical and methodological aspects of the paper are dealt with in section 3. Section 4 is devoted to the analysis of CGE simulation results, where these are associated with observed trends. Lastly, the main conclusions and policy implications of the paper are summarized in section 5 .

\section{II}

\section{Trade policy reforms and socio-economic performance}

During the past two decades, Costa Rica, El Salvador and Honduras, like the rest of Central America, have promoted exports and rapidly liberalized imports with the aim of achieving high and sustained exportled growth and, eventually, reducing poverty. These

$\square$ The author is grateful to Ana Sojo, José Cuesta, Matthew Hammill and Pablo Sauma for their valuable comments on earlier versions of this paper. The views and opinions expressed herein are those of the author and do not necessarily reflect those of the United Nations or its Member States. countries have instituted special export regimes and restructured their export procedures. Temporary tax credit certificates were heavily used at one stage to subsidize non-traditional exports. Tax exemptions on imports of raw materials and capital goods have been extended to export producers. Quantitative restrictions and import surcharges have been phased out and customs procedures simplified. Furthermore, the three countries have signed free trade agreements with other nations, including one whose other signatories are the Dominican Republic and the United States of America 
(commonly known as CAFTA-DR), and all of them are active members of the World Trade Organization (WTO). All these reforms have been reflected in a remarkable decline in taxes on international trade. Not only have import tariff rates been cut sharply, but export taxes have essentially been abolished (figure 1).

The three countries considered here have opted for fairly similar trade policy reforms; in fact, they have followed the broader Latin American trade policy pattern. Their trajectories with regard to export-led growth and poverty have been divergent, however. Exports have risen in all three countries (table 1), but genuine export-led growth has been achieved only in Costa Rica (Sánchez and Sauma, 2006). Exports from El Salvador did expand considerably in the 1990s, but non-tradable sectors seem to have been more important engines for the country's unimpressive economic growth (Acevedo, 2004). Exports have grown less rapidly in Honduras (Cuesta and Sánchez, 2004).
Export diversification has been a precondition of export-led growth. A wide range of agricultural and manufacturing goods, some of them produced by infant high-tech industries, have gone to make up Costa Rica's export supply. Non-traditional exports have expanded impressively in Costa Rica, accounting for nearly $80 \%$ of merchandise exports in 2000-2003 (table 1), and are going to a growing number of trading partners. Honduras and El Salvador, on the other hand, have not treated export diversification as a primary goal, but have instead relied more on the development of the drawback industry commonly termed the "maquila" industry, which mainly produces textiles and clothing for export, especially to the United States. By 2000-2003, Honduran non-traditional exports were not exceeding $45 \%$ of merchandise exports each year, whereas maquila exports had risen to more than $30 \%$ of merchandise exports. Non-traditional exports from El Salvador have grown, but maquila exports

Costa Rica, El Salvador and Honduras: average effective nominal tax rates on exports and imports, ${ }^{a}$ 1990-2003

(Percentages)

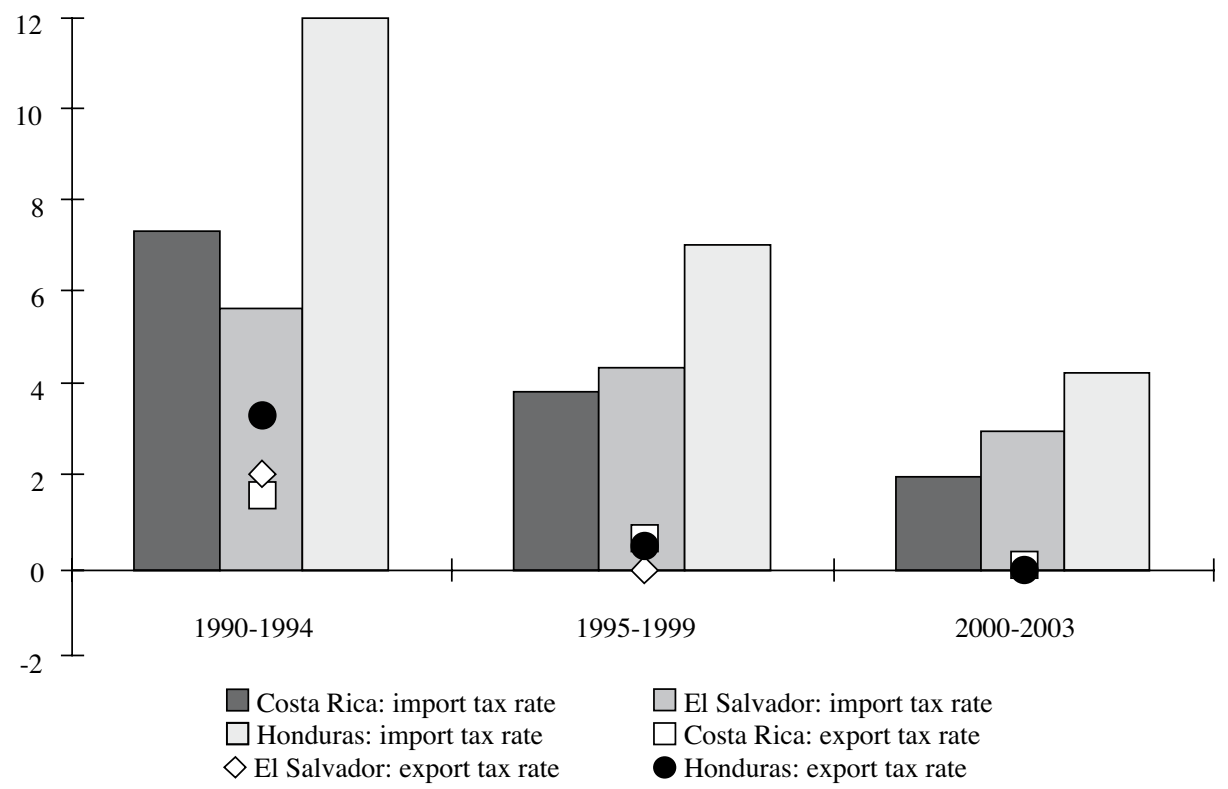

Source: prepared by the author on the basis of data from the Economic Commission for Latin American and the Caribbean (ECLAC).

a Estimated on the basis of collected export- and import-tax revenues and export and import value. 
have contributed more than half of all merchandise exports since 1999 .

Trade liberalization has spurred imports but, once again, patterns differ (table 1). Imports of raw materials and capital goods have increased consistently in Costa Rica as export growth has allowed the country to build up its capacity to generate foreign exchange. In the other two countries, most especially El
Salvador, imports of intermediate inputs for maquila production have soared, and for this reason net maquila exports have not been particularly high. As a source of foreign exchange, El Salvador and Honduras have been more reliant on workers' remittances, especially from the United States, as these have averaged more than $62 \%$ and $86 \%$, respectively, of the external goods and services balance in the years since 1995 (table 1).

TABLE 1

Costa Rica, El Salvador and Honduras: macroeconomic indicators, 1990-2003 (Annual averages for the period)

\begin{tabular}{|c|c|c|c|c|}
\hline Indicator & Country & 1990-1994 & 1995-1999 & $2000-2003$ \\
\hline \multirow[t]{3}{*}{ Employment (annual growth rate) } & Costa Rica & 2.8 & 2.8 & 6.3 \\
\hline & El Salvador & 7.6 & 3.1 & 3.8 \\
\hline & Honduras & 4.6 & 5.2 & -0.5 \\
\hline \multirow{3}{*}{$\begin{array}{l}\text { Goods and services exports } \\
\text { (annual growth rate) }\end{array}$} & Costa Rica & 9.2 & 14.8 & 1.0 \\
\hline & El Salvador & 13.7 & 13.0 & 6.4 \\
\hline & Honduras & -0.9 & 2.7 & 3.0 \\
\hline \multirow{3}{*}{$\begin{array}{l}\text { Exports of non-traditional goods } \\
\text { (percentage of merchandise exports) }\end{array}$} & Costa Rica & 50.5 & 67.9 & 79.5 \\
\hline & El Salvador & 48.4 & 34.1 & 34.8 \\
\hline & Honduras & 36.3 & 42.7 & 44.0 \\
\hline \multirow{3}{*}{$\begin{array}{l}\text { Exports from drawback industries } \\
\text { (percentage of merchandise exports) }\end{array}$} & Costa Rica & 13.6 & 9.0 & 6.5 \\
\hline & El Salvador & 17.5 & 45.8 & 57.8 \\
\hline & Honduras & 4.8 & 20.0 & 31.4 \\
\hline \multirow{3}{*}{$\begin{array}{l}\text { External goods and services balance } \\
\text { (percentage of GDP) }\end{array}$} & Costa Rica & -5.4 & -1.5 & -1.8 \\
\hline & El Salvador & -14.5 & -12.9 & -15.3 \\
\hline & Honduras & -7.5 & -7.7 & -15.9 \\
\hline \multirow[t]{3}{*}{ GDP (annual growth rate) } & Costa Rica & 5.4 & 5.4 & 3.0 \\
\hline & El Salvador & 5.9 & 3.9 & 2.1 \\
\hline & Honduras & 2.8 & 2.7 & 3.6 \\
\hline \multirow{3}{*}{$\begin{array}{l}\text { Goods and services imports } \\
\text { (annual growth rate) }\end{array}$} & Costa Rica & 9.9 & 9.2 & 2.2 \\
\hline & El Salvador & 20.1 & 8.8 & 6.2 \\
\hline & Honduras & 3.8 & 3.4 & 2.8 \\
\hline \multirow{3}{*}{$\begin{array}{l}\text { Imports of consumer goods } \\
\text { (percentage of merchandise imports) }\end{array}$} & Costa Rica & 21.6 & 20.6 & 18.7 \\
\hline & El Salvador & 26.0 & 24.2 & 26.0 \\
\hline & Honduras & 21.4 & 24.9 & 29.6 \\
\hline \multirow{3}{*}{$\begin{array}{l}\text { Imports of raw materials and capital goods } \\
\text { (percentage of merchandise imports) }\end{array}$} & Costa Rica & 78.0 & 79.4 & 81.3 \\
\hline & El Salvador & 66.3 & 56.5 & 50.2 \\
\hline & Honduras & 76.8 & 71.9 & 67.9 \\
\hline \multirow{3}{*}{$\begin{array}{l}\text { Imports of other goods } \\
\text { (percentage of merchandise imports) }^{\mathrm{a}}\end{array}$} & Costa Rica & 0.5 & 0.1 & 0.0 \\
\hline & El Salvador & 7.7 & 19.3 & 23.8 \\
\hline & Honduras & 1.8 & 3.2 & 2.5 \\
\hline \multirow{3}{*}{$\begin{array}{l}\text { Net workers' remittances from abroad } \\
\text { (percentage of goods and services trade balance) }\end{array}$} & Costa Rica & $-\mathrm{b}$ & 13.8 & 16.0 \\
\hline & El Salvador & 70.9 & 84.8 & 88.7 \\
\hline & Honduras & 58.0 & 62.0 & 62.5 \\
\hline
\end{tabular}

Source: estimates on the basis of ECLAC data, except for remittances and GDP data, which are from the World Bank, World Development Indicators [online database] http://devdata.worldbank.org/dataonline/.

a "Other goods" are basically imports for drawback industries (maquila).

b Workers' remittances from abroad were too small to be accounted for separately in the balance of payments. 
Export growth has put Costa Rica in a position to reduce its trade deficit despite rising imports, but the same is not true of the other two countries.

In the 1990s, economic growth was $5.4 \%$ and $4.9 \%$ per annum in Costa Rica and El Salvador, respectively, and just below 3\% per annum in Honduras (table 1). The first two countries experienced a major economic slowdown in 2000-2003 as world prices for some of their key export commodities plunged, while Honduras was able to sustain its modest growth. ${ }^{1}$ An outstanding trade performance and agricultural growth of more than $4 \%$ in the 1990 s are indications that comparatively-advantaged export sectors have been a source of economic growth for Costa Rica (Sánchez, 2004). Yet growth has been fairly evenly balanced in Costa Rica, with export-oriented industrial sectors and trade-related services also expanding satisfactorily (Sánchez and Sauma, 2006). In spite of trade policy reforms, non-tradable sectors have paradoxically been

\footnotetext{
${ }^{1}$ The period of analysis is 1990-2003, but it is worth mentioning that the Costa Rican economy recovered during 2004-2005, growing by just over $4 \%$. El Salvador also continued to grow in the same period, although by little more than $2 \%$ per annum. Economic growth in Honduras was roughly on a par with that in Costa Rica.
}

of more fundamental significance for growth in El Salvador and Honduras (Acevedo, 2004; Cuesta and Sánchez, 2004). Comparatively-advantaged sectors have not been boosted by the reforms as expected in those two countries; for example, agricultural growth has been meagre, particularly in the 1990s (Sánchez, 2005).

The incidence of poverty is not as high in Costa Rica as in El Salvador and Honduras; even Costa Rica's rural poverty is lower than urban poverty in the other two countries (table 2). In the 1990s, the evolution of employment and real wages helped reduce poverty in Costa Rica and El Salvador (tables 1 and 2 ). This trend could not be sustained into the new millennium in Costa Rica, as the economy slowed down and income distribution as measured by the Gini coefficient became more uneven (table 2). ${ }^{2}$ Poverty did continue to fall in El Salvador in spite of the economic slowdown because, even though real

\footnotetext{
${ }^{2}$ The level of employment in Costa Rica rose substantially into the new millennium even as the economy slowed (table 1). This, however, was due to rising informality in the labour market.
}

TABLE 2

Costa Rica, El Salvador and Honduras: incidence of poverty, and level and distribution of real incomes, selected years of the 1990-2004 period

\begin{tabular}{|c|c|c|c|c|c|c|c|}
\hline \multirow[t]{2}{*}{ Country } & \multirow[t]{2}{*}{ Year } & \multicolumn{2}{|c|}{$\begin{array}{l}\text { Real wage per worker } \\
\text { (monthly, US\$) }\end{array}$} & \multirow[t]{2}{*}{$\begin{array}{l}\text { Gini coefficient } \\
\text { of per capita } \\
\text { income }\end{array}$} & \multicolumn{3}{|c|}{$\begin{array}{l}\text { Incidence of poverty } \\
\text { (percentage of population } \\
\text { below the poverty line) }\end{array}$} \\
\hline & & Urban & Rural & & Urban & Rural & National \\
\hline \multirow[t]{5}{*}{ Costa Rica } & 1990 & 306 & 207 & 0.44 & 24.8 & 27.3 & 26.2 \\
\hline & 1997 & 450 & 327 & 0.45 & 19.3 & 24.8 & 22.5 \\
\hline & 1999 & 510 & 337 & 0.47 & 18.1 & 22.3 & 20.3 \\
\hline & 2002 & 521 & 355 & 0.49 & 17.5 & 24.3 & 20.3 \\
\hline & 2004 & 483 & 341 & 0.48 & 18.7 & 23.1 & 20.5 \\
\hline \multirow[t]{5}{*}{ El Salvador } & 1995 & 197 & 86 & 0.51 & 45.8 & 64.4 & 54.2 \\
\hline & 1997 & 252 & 103 & 0.51 & 44.4 & 69.2 & 55.5 \\
\hline & 1999 & 281 & 147 & 0.52 & 38.7 & 65.1 & 49.8 \\
\hline & 2001 & 272 & 108 & 0.53 & 39.4 & 62.4 & 48.9 \\
\hline & 2004 & 259 & 133 & 0.49 & 41.2 & 56.8 & 47.5 \\
\hline \multirow[t]{5}{*}{ Honduras } & 1990 & 148 & 55 & 0.62 & 69.8 & 88.0 & 80.5 \\
\hline & 1997 & 114 & 60 & 0.56 & 72.6 & 84.2 & 79.1 \\
\hline & 1999 & 157 & 87 & 0.56 & 71.7 & 86.3 & 79.7 \\
\hline & 2002 & 192 & 72 & 0.59 & 66.7 & 86.1 & 77.3 \\
\hline & 2003 & 186 & 60 & 0.59 & 62.7 & 84.8 & 74.8 \\
\hline
\end{tabular}

Source: Economic Commission for Latin America and the Caribbean (ECLAC), Social Panorama of Latin America $2002-2003$ (LC/ G.2209-P), Santiago, Chile, 2003. United Nations publication, Sales No.E.03.II.G.185; and Social Panorama of Latin America 2006 (LC/G.2326-P), Santiago, Chile, 2006. United Nations publication, Sales No.E.06.II.G.133. 
wages by and large decreased, income distribution improved as remittances flowed into the country, and particularly into rural areas. Since trends in real wages and income inequality did not favour the urban population, however, the number of urban poor rose. In Honduras, on the other hand, employment, real wages and income distribution evolved satisfactorily on the whole in the 1990s, but poverty showed only a modest decline between 1990 and 1999. Developments in the labour market became more unfavourable to
Honduran workers as the new millennium began, since income distribution worsened too. Nonetheless, inflows of remittances into Honduras favoured the poor, even though income distribution worsened because remittances went mainly to urban areas, and rural workers experienced a greater decline in real wages. Only in Honduras was income distribution more equal in 2003 or thereabouts than in 1990, and there is no clear evidence that this was a result of the country's trade policy reforms.

\section{III}

\section{Analytical and methodological issues}

Trade policy has been reformed in Central America in order to raise the relative prices or profitability of exportable goods and services (hereafter, exportables) with a view to promoting export-led growth. Export promotion policies aim directly at this result. Tariff reductions, meanwhile, would be expected to lower the cost of imported inputs used in export production, i.e., to reduce the price of imported goods and services (hereafter, importables) relative to exportables. The relative prices of exportables and importables (i.e., tradables) would also rise if domestic liberalization led to a reduction in the domestic prices of non-tradable goods and services (hereafter, non-tradables).

This kind of relative price adjustment would ultimately affect the relative remuneration of workers (i.e., income distribution), as can be concluded from the Heckscher-Ohlin-Samuelson (HOS) framework of traditional trade theory and its extensions (Salvatore, 1995; Evans, 1989; Wood, 1994) or, alternatively, from the dependent economy model that comes out of the literature on small-open developing economies (Cox-Edwards and Edwards, 1994; Edwards, 1988). These theories were not in fact formulated to explain the poverty effects of trade policy, although the issue has recently been studied empirically. ${ }^{3}$ In addition, they tend to overlook the effects that internal and external factors other than trade policy can also have on relative prices. World price shocks and nominal

\footnotetext{
${ }^{3}$ See, for example, Ganuza and others (2002 and 2004), Sánchez (2004 and 2005) and Vos and others (2006), among other studies.
}

exchange-rate adjustments, for example, affect the prices of tradables. Inflows of capital and remittances could also affect relative prices through the real exchange rate, among other factors.

A shift in relative prices, whether resulting from macroeconomic policies or from an external shock, will affect consumer prices and hence goods and services markets. Shifts in sales revenues and input costs will alter the relative profitability of sectors, in response to which producers' investment choices will change. Household consumption will probably adjust too, although the ultimate effect will depend on other factors affecting household income, i.e., the labour market, government transfers and remittances from abroad. The government may adjust spending in response to changes in tax revenue or social policy objectives, triggering second-round effects in goods and services markets. All these changes will be accompanied by supply and demand adjustments in factor markets. The ultimate consequences for domestic absorption will also depend partly upon the impact on factor income and may have feedback effects in the demand system by way of further price adjustments.

Producers' demand for factors will shift as the relative profitability of sectors changes, and this will affect the level and possibly the composition of labour demand, with repercussions for the level and distribution of labour income, especially if the labour supply responds simultaneously. The effects on the level and distribution of household income would presumably reproduce the changes in labour income, but this may not necessarily be the case if households 
receive government transfers and remittances, and if non-poor households receive non-labour incomes. The ultimate impact, primarily upon the level and distribution of household income but also upon consumer prices, will determine the capacity of households to satisfy their basic consumption needs, and hence their level of income poverty.

Macroeconomic adjustments will eventually be added to this multiplicity of transmission mechanisms, and their interaction will probably also depend on other internal factors such as technological change, human capital endowments, productivity and so on. A CGE framework is required to capture most of such a wide range of transmission mechanisms and interrelated effects, and their ultimate impact on the poor.

A static CGE model for each of the three countries studied was used to generate simulation results that, combined with actual trends, helped to substantiate this paper's assertions. The model shares most of its features with the widely used CGE model developed at the International Food Policy Research Institute (IFPRI), which is fully explained in Löfgren and others (2002). ${ }^{4}$ This model belongs to the family of neoclassical CGE models with certain structuralist characteristics, developed for trade policy analysis, the theoretical foundations for which can be found in Dervis and others (1982) and Robinson (1989). It is a model well suited to performing analyses of policy and external shocks and gauging how these shocks affect relative prices and hence the allocation of resources and income distribution. A particular feature of the model is the inclusion of imperfect substitution functions whereby, given a change in relative prices at given elasticity values: (i) the producer substitutes between intermediate goods and factors of production, (ii) the producer substitutes between factors of production, (iii) the producer substitutes between the domestic market and exports in the allocation of output, and (iv) the consumer substitutes between consumption of domestically-produced output and consumption of imported goods.

The database for the base-year calibration of each country's CGE model comes from a social accounting matrix (SAM) and elasticity and factor stock data. The SAM provides the accounting consistency and the dimensions of the model (that is, the number of production activities, goods and services, factors and institutions). The elasticities, meanwhile, define

\footnotetext{
${ }^{4}$ Only a few minor changes were introduced with respect to the model in Löfgren and others (2002), as detailed in Sánchez (2005).
}

the degree of substitution as one of the optimization problems facing both producers and consumers in response to a change in relative prices.

The data for Costa Rica were originally compiled in Sánchez (2004) to conduct an analysis of how trade reform had affected poverty in the country. Similar studies for the trade-poverty nexus have been conducted for El Salvador and Honduras, as reported in Ganuza and others (2004), and both the SAMs and the other data required have been borrowed from those studies for the purposes of the present one. The SAMs of Costa Rica and Honduras are for 1997 whereas that of El Salvador is for 1999, these being the respective base years of each country's CGE model.

The SAMs go into considerable sectoral detail (that is, they are broken down into a large number of activities and goods and services), with variations between the countries reflecting their different production structures. The main export products are duly identified, whereas sectors that play only a fairly small part in the economy are aggregated. All other accounts in the SAMs, dealing with factors and institutions, are set up in a more standard way. Labour, in particular, is classified according to skill level and occupational category. The elasticities are all defined at the sectoral level (that is, for both activities and goods and services) in order to reflect sector-specific behaviour for the producer and the consumer. Even though the data inputted into the model necessarily differ by country in terms of disaggregation and the values given, the simulation results are comparable as the model's functions do not differ by country.

Any typical SAM-based CGE model provides results for inter-group income inequality across different groups of households. It would not produce any result for intra-group inequality, however, even though this is also important in explaining total income inequality and poverty. In trying to remedy this limitation, each country's CGE model was combined with a microsimulation methodology originally developed by Almeida dos Reis and Paes de Barros (1991) to analyse earnings inequality. This method was further developed to analyse per capita household income inequality and poverty in a CGE framework, as explained in Ganuza and others (2002).

The microsimulation methodology essentially isolates changes in inequality and poverty due to labour market adjustments. The CGE model provides a baseyear labour market structure identical to the one that would be calculated from the household survey data used to calibrate the model and to compute base-year 
inequality and poverty measures. ${ }^{5}$ Any CGE simulation of a policy or external shock can be used to generate a counterfactual labour market structure that is then imposed in a sequential, top-down fashion on the household survey data in order to generate random numbers from a normal distribution. This has two objectives: first, to determine how many individuals of working age change their participation status or move from one segment of the labour market to another as a result of the situation simulated, and second, to assign labour incomes to newly employed individuals using the mean income of the decile of the distribution to which previously employed workers with identical socio-economic characteristics belonged. It is assumed that, on average, the effects of the random changes correctly reflect the impact of actual changes in the labour market. Since labour supply and occupation decisions are approximated as largely random processes, the microsimulations are repeated several times in Monte Carlo fashion to allow construction of $95 \%$ confidence intervals for the indices of inequality and poverty. ${ }^{6}$ The latter are compared with base-year indices of inequality and poverty so that conclusions can be drawn. All individuals in the household survey database are accounted for in determining the income distribution impact.

\section{IV}

\section{Analysis of simulation results}

Once calibrated and feasibly solved using the General Algebraic Modelling System (GAMS) with data for each of the three countries, the CGE model was used to conduct various policy and external shock simulations. The results are discussed in this section and are reported in table 3 as percentage deviations from the base-year solution value. Most simulations were conducted under a set of initial closure rules designed to ensure equilibrium in the different markets covered by the CGE models. In the factor market, for example, quantities allow for an "equilibrium" to be reached for capital, unskilled wage labour and self-employed labour (unskilled and skilled). The employment level of skilled wage labour is fixed, and the wage equilibrates this factor's market. The difference between current government revenues and current government expenditures is made up by government savings. The current account balance with the rest of the world clears through foreign savings, and the exchange

\footnotetext{
${ }^{5}$ The labour market structure, whether for the base-year solution or a simulation, is defined by economic participation and unemployment rates; employment structure, as defined by sector of economic activity and occupational category; remuneration structure, as defined by sector of economic activity; average remuneration in the economy; and composition of the employed labour force by skill level. For more detail, see Ganuza and others (2002).

${ }^{6}$ Endogenous poverty and indigence lines were calculated using the price and expenditure systems of the CGE model, following the procedure spelled out in Sánchez (2005). These lines were used to compute poverty indices after each microsimulation, considering that policy and external shocks typically affect the prices of basic consumer goods and services.
}

rate is kept fixed, consistently with the predominant exchange-rate regimes of the three countries in the base year. Only this external-sector closure rule was changed to conduct some simulations. Savings were made equal to investment using a "balanced" closure rule whereby adjustments in absorption were spread proportionally across all its components. Investment and government consumption were assumed to be a fixed share of base-year nominal absorption and, given this specification, the residual share for household consumption was also fixed implicitly. The saving rates of households and enterprises were adjusted by an equal number of percentage points such that aggregate savings equalled aggregate investment. ${ }^{7}$

\section{Trade policy reforms}

The trade policy reform that was simulated consists of a $50 \%$ reduction in import tariffs for all imported goods and services (import liberalization) and a 50\% reduction in export taxes for all exported goods and services (export promotion). ${ }^{8}$ The magnitude of the

\footnotetext{
${ }^{7}$ This "neutral" macro closure reduces the risk of erratic swings in macro aggregates when simulations cause trade or fiscal balances to change substantially.

${ }^{8}$ Since no export tax rate was recorded in the El Salvador SAM, the export promotion measure for that country was simulated by means of a $50 \%$ rise in the implicit export price subsidy for nontraditional agricultural exports (all agricultural exports except coffee, cotton, sugar cane and basic grains).
} 


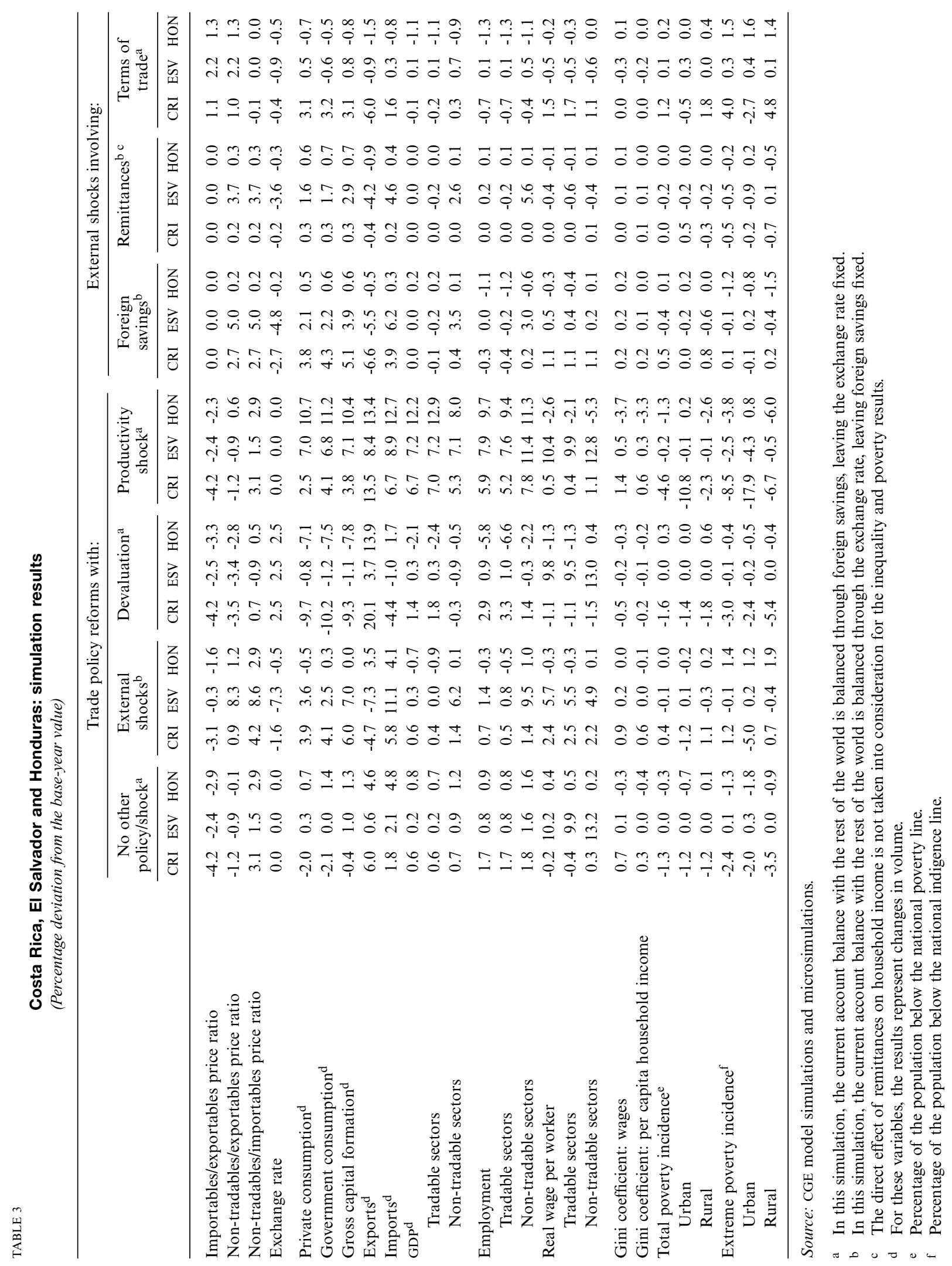


policy shocks involved was set deliberately high to simulate a bold trade policy reform. ${ }^{9}$ These policy shocks were also made to affect all tradable (importable and exportable) sectors uniformly to avoid reforming protection for some sectors more than others. Since the model's "rest of the world" sector does not distinguish trade flows by origin and destination, the simulated import liberalization and export promotion policies do not discriminate between trading partners. As these considerations clearly show, the objective of the simulations was to generate comparative static results rather than simulate an actual trade agreement.

The results from this trade policy reform simulation are fairly consistent with what Costa Rica has experienced in reality. Domestic final demand initially increases in that country as import liberalization is simulated, but subsequently resources are shifted rapidly away from domestic market production into export sectors in response to the export promotion measure. The reduction in supply for the domestic market translates into lower domestic absorption. Non-tradable production does not contract, however, but actually rises more or less in tandem with tradable production owing to strong linkages with the export sector. ${ }^{10}$ The simulated export promotion measure likewise reduces production for the domestic market in El Salvador and Honduras, but in these countries, unlike Costa Rica, this does not fully offset the benefits from lower tariffs. These results accord with the paradoxical fact, referred to above, that economic activity in non-tradable sectors has been a crucial factor in overall growth during the trade policy reforms in El Salvador and Honduras. Output increases by $0.6 \%, 0.2 \%$ and $0.8 \%$ in Costa Rica, El Salvador and Honduras, respectively; yet, again in accordance with the actual facts, it is only in Costa Rica that production increases more steadily in the tradable and non-tradable sectors and that export growth is sufficient to reduce the trade deficit. In the other two countries, output rises more strongly in non-tradable sectors and imports increase by more than exports.

Employment increases slightly faster than output, especially in Costa Rica, essentially because

\footnotetext{
${ }^{9}$ Despite the relatively large magnitude of the simulated change to trade policy instruments, the models for the three countries remained stable after these were applied, and they were feasibly solved.

${ }^{10}$ Sánchez (2007) argues that export diversification in Costa Rica opened the way to changes in the production structure that have ultimately led to the creation of production linkages between sectors.
}

no endogenous linkage between trade policy and productivity is modelled. Again, the shift in employment is spread more evenly across tradable and non-tradable sectors in Costa Rica, and this is partly explained by the fact that the export promotion measure encourages agricultural employment too. More of the newly employed labour in El Salvador and Honduras goes into non-tradable than tradable sectors, essentially owing to the prevalent effect of the tariff cut. This seems to determine the final position of wages in the two countries, where they rise above their base-year values, especially in El Salvador. The wage effect of the export promotion measure offsets that of import liberalization, partially in Honduras and fully in Costa Rica, where there is a small reduction overall. The simulated import tariff reduction unambiguously widens the wage gaps between wage earners and selfemployed workers, and between skilled and unskilled workers, in all three countries (not shown in table 3). Labour income distribution as measured by the Gini coefficient worsens in Costa Rica and El Salvador. In Honduras, by contrast, the employment adjustment leads to a reduction in labour income inequality. The export promotion measure reinforces the disequalizing effect in Costa Rica because of its impact upon the structure of employment by worker type. The opposite effect is observed in El Salvador, where the labour income gap between skilled and unskilled workers narrows when exports are promoted. No major change is observed in Honduras in this respect. Taken all together, the simulated trade policy reforms worsen the distribution of wages in Costa Rica just slightly and bring about a small improvement in Honduras, while in El Salvador there is little change. These distributive effects are broadly reproduced at the per capita household income level.

The combination of increased household labour incomes and a small drop in basic consumption costs leads to a reduction in the incidence of poverty, especially in Costa Rica. Had income distribution not deteriorated, the poverty reduction in the simulation would have been more substantial for Costa Rica. The improvement in income distribution helps to reduce poverty in Honduras. The incidence of poverty remains basically unchanged in El Salvador, however, where a very slight increase in wage inequality seems to weigh disproportionately upon that in extreme poverty in urban areas. The incidence of poverty falls the most in Costa Rica because those living in extreme poverty in rural areas are much better off than in the other two countries. 
As indicated earlier, income inequality in Costa Rica rose in 1997-2002 while, by and large, the incidence of poverty fell, especially in rural areas (table 2). These facts accord with the simulation results. ${ }^{11}$ Honduras undertook trade policy reforms similar to those of Costa Rica in the same period, only less rapidly, and it witnessed a reduction in the incidence of poverty overall, although income inequality worsened between 1999 and 2002. According to the simulation results, the trade policy reforms must have helped to reduce extreme poverty in Honduras by way of higher employment and wages. However, worsening income distribution must have been fully offset by the distributive effect of remittance inflows. Trade policy reforms have not been leading determinants of income inequality and poverty in El Salvador, where inflows of remittances have had a more predominant influence. In summary, the combination of simulation results and actual events suggests that it is in Costa Rica that trade policy reforms have most clearly influenced the evolution of poverty and income inequality. In what follows, an attempt will be made to explain why.

\section{Trade policy reform, exchange rates and export competitiveness}

As noted earlier, trade policy reforms have been aimed at increasing the relative profitability of exports. Various external factors have, however, exerted pressure on the real exchange rate (RER) to appreciate, thus pushing

${ }^{11}$ It is worth recalling at this point that the CGE model's base year is 1997 for Costa Rica and Honduras and 1999 for El Salvador. down the relative profitability of exports. These include growing inflows of remittances (table 1), but also other private capital flows and FDI, which began to be attracted in substantial volumes in the early 1990s as capital controls were dismantled, greater economic and political stability was achieved and various incentives for foreign investors were instituted (table 4). Furthermore, recurring episodes of global price declines for key export goods and services, such as coffee and sugar, and skyrocketing oil prices worsened the terms of trade for these countries at the beginning of the new millennium, thus exerting further pressure on the RER (table 4). There is no obvious prospect of a sustained reversal in this trend. Some of the Central American countries' key export goods and services recently rose in value, but they have been falling back again as the world economy slowed down. The prices of oil and some imported food staples have continued to increase on the whole, despite the slowdown in the global economy.

The CGE model was also used to simulate a $25 \%$ increase in capital inflows, a $25 \%$ increase in remittances, and a $5 \%$ drop in the world price of major exports (a terms-of-trade shock). ${ }^{12}$ These are considered external shocks for the purposes of the analysis presented in this section. The increase in capital inflows was simulated by changes to foreign savings, showing them as fixed and exogenous, while the current account with the

\footnotetext{
12 To simulate the terms-of-trade shock, the world export price was changed in the CGE models for goods and services accounting for about $30 \%$ of each country's total exports ("non-traditional agricultural commodities" in Costa Rica, "other services" in El Salvador and "food, beverages and tobacco" in Honduras).
}

TABLE 4

Costa Rica, El Salvador and Honduras: gross private capital and FDI inflows and net terms of trade, 1990-2003

(Annual averages for the period)

\begin{tabular}{|c|c|c|c|c|}
\hline Indicator & Country & $1990-1994$ & $1995-1999$ & $2000-2003$ \\
\hline \multirow[t]{3}{*}{ Gross private capital inflows (percentage of GDP) } & Costa Rica & 5.3 & 8.7 & 9.2 \\
\hline & El Salvador & 1.3 & 6.2 & 15.2 \\
\hline & Honduras & 6.8 & 7.5 & 7.6 \\
\hline \multirow[t]{3}{*}{ Net FDI (percentage of GDP) } & Costa Rica & 2.7 & 3.6 & 3.1 \\
\hline & El Salvador & 1.3 & 2.5 & 3.5 \\
\hline & Honduras & 0.2 & 2.4 & 1.9 \\
\hline \multirow[t]{3}{*}{ Net terms of trade $(2000=100)$} & Costa Rica & 84.9 & 105.1 & 100.3 \\
\hline & El Salvador & 83.5 & 113.0 & 94.5 \\
\hline & Honduras & 83.4 & 103.3 & 95.1 \\
\hline
\end{tabular}

Source: World Bank, World Development Indicators [online database] http://devdata.worldbank.org/dataonline/. 
rest of the world cleared through the exchange rate in accordance with the alternative to the original model closure. This alternative rule was used to simulate the increase in remittances too, since the expectation is that they may also have a large effect on the exchange rate. The increase in remittances was simulated by scaling up transfers from abroad to households in the CGE model, but the effect on income distribution and poverty was analysed in two stages. In the first stage, the rise in household income derived from remittances was omitted from the microsimulations. In other words, the initial analysis of income distribution and poverty in the remittances simulation only deals with the "pure" relative price effect of remittances flowing through the labour market. The "full" effect of remittances on income distribution and poverty was then analysed in a second stage in which the increase in household incomes was included in the microsimulations.

The three external shocks that were simulated lead to a large appreciation of the RER (table 3). Resources are allocated away from tradable sectors into non-tradable ones because of the relative price effect. Domestic absorption rises as a result, but production barely increases because the trade balance deteriorates and tradable production is adversely affected relative to non-tradable production, the exception being the terms-of-trade shock in Honduras. ${ }^{13}$

Employment shrinks most in tradable sectors, especially agriculture, although some of the simulations also show lower employment in non-tradable sectors in Costa Rica and Honduras. Increased recruitment in non-tradable sectors in El Salvador offsets lower employment in tradable sectors, so that total employment either increases slightly or remains virtually unchanged. The fall in domestic prices triggered by RER appreciation pushes wages down, except in Costa Rica in all three simulations and El Salvador when higher capital inflows are simulated, since these are situations where higher demand for skilled wage earners in non-tradable sectors ultimately pushes wages up. The upsurge in non-tradable sectors translates into larger wage gaps between wage earners and the selfemployed, and between skilled and unskilled workers, except in the case of the El Salvador terms-of-trade

\footnotetext{
${ }^{13}$ More atypically, the simulated terms-of-trade shock reduces nontradable production in Honduras by almost $1 \%$. This is because the simulated increase in the world price of food, beverages, and tobacco discourages production of those goods for the domestic market, and domestic demand for domestically produced goods and imports falls as a result.
}

shock. As a result, income distribution as measured by the Gini coefficient worsens very slightly. The effect on poverty is more ambiguous. The total incidence of poverty rises in Costa Rica overall as labour incomes drop in rural areas, except when remittances are increased, as these reduce the numbers living in extreme poverty, particularly in rural areas. The upsurge in non-tradable sectors unambiguously reduces extreme poverty in Costa Rica's urban areas. In El Salvador, raising capital inflows, including remittances, leads to a modest reduction in total and extreme poverty as a consequence of the redistributive impact of labour market changes in non-tradable sectors. There is a reduction in extreme poverty in Honduras too, particularly in rural areas, but this is explained by the downward pressure on food prices. The terms-of-trade shock proves somewhat detrimental in terms of the incidence of poverty in El Salvador and Honduras owing to its effects on household income, which tend to be most severe for the poorest.

The simulation results indicate that, on the whole, inequality and poverty are weakly explained by the simulated increase in capital inflows, including remittances, and the unfavourable terms-of-trade shock. However, the effect of remittances deserves more indepth examination since, as indicated earlier, only the "partial" impact arising through the operation of the labour market alone has been analysed. When transfers to households are also taken into consideration in the microsimulations, the impact on income inequality and poverty is much more noticeable in El Salvador and Honduras, where remittances account for a large share of the trade balance (table 1). As figure 2 shows, the distribution of per capita household income improves markedly in El Salvador, where the bulk of remittances flow to rural areas, but deteriorates in Honduras, where most remittances go to urban households. The numbers of people living in moderate and extreme poverty fall sharply, but this effect is much more marked in El Salvador on account of the improvement in income distribution. The results for Costa Rica are not reported here because they were very close to zero, the reason being that the scale of remittances was substantially smaller there than in the other two countries in the model base year. ${ }^{14}$

\footnotetext{
${ }^{14}$ Even today, the scale of remittances remains much smaller in Costa Rica. According to the World Bank, World Development Indicators 2006, net worker remittances from abroad were equivalent to $19.1 \%, 93.8 \%$ and $96.3 \%$ of the goods and services trade balance in Costa Rica, El Salvador and Honduras, respectively.
} 


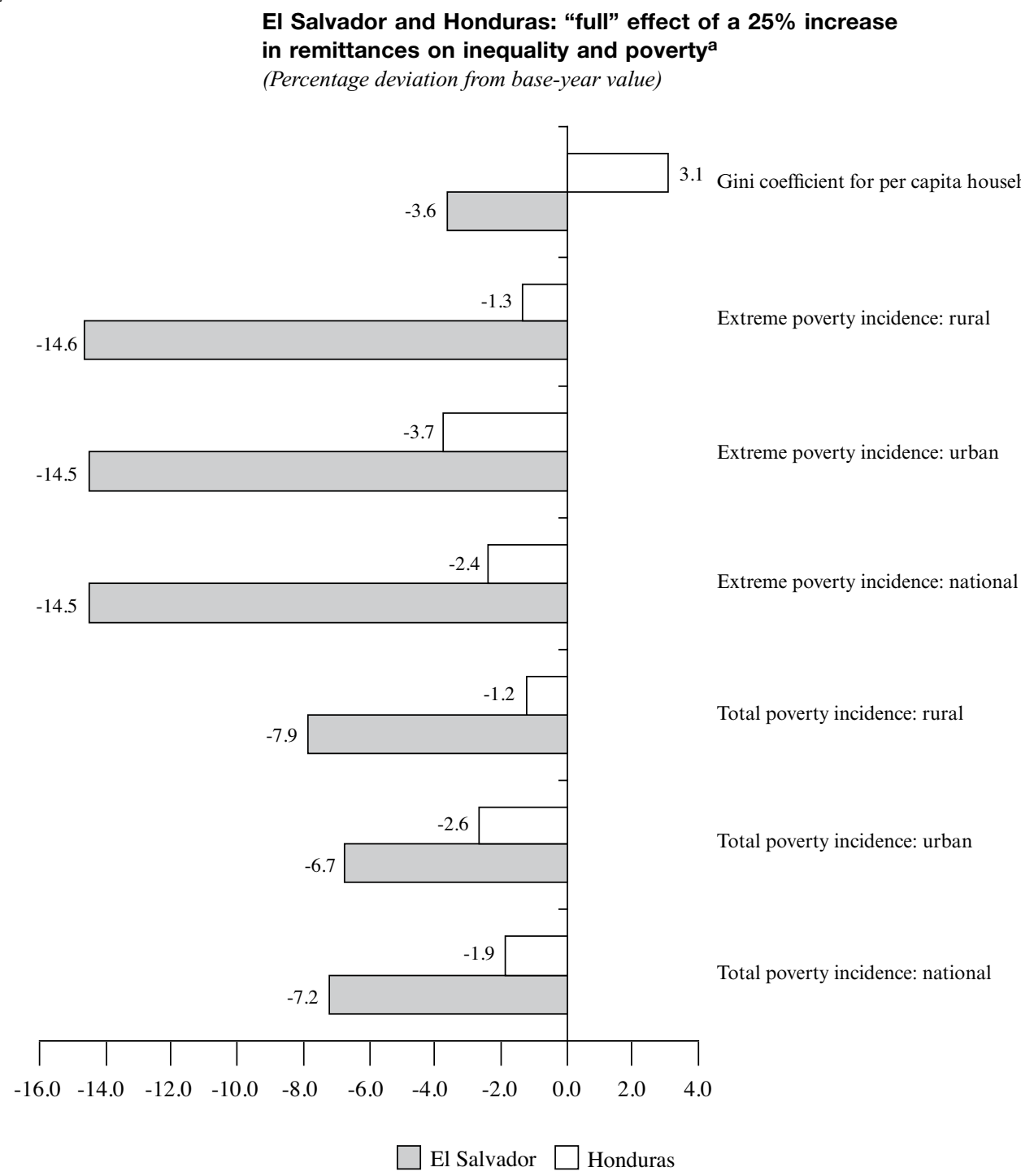

Source: CGE models and microsimulations.

a Estimates take account of the direct effect of remittances on household income in the microsimulations.

The relative price effect of remittances on production is found to be negligible and the impact on income distribution and poverty is essentially explained by the boost to household incomes from direct transfers. ${ }^{15}$ This result may indicate that El Salvador and Honduras lack the capacity to absorb remittance

${ }^{15}$ This conclusion still holds if the initial model closure rule (fixed exchange rate and current account with the rest of the world balanced through foreign savings) is maintained. inflows productively and that the export sector in those countries is seriously affected by the resulting appreciation of the RER. Should these circumstances persist over time in El Salvador and Honduras, where remittances are still growing systematically, those countries may end up suffering from what Sánchez (2005) calls "remittance disease".

The implications of RER appreciation are important for the relative success of trade policy reforms, as is indicated by the results of a new simulation combining 
these reforms with external shocks. ${ }^{16}$ The appreciation of the exchange rate, basically triggered by the external shocks, boosts consumption, investment and imports in comparison with the situation in which trade policy reforms are unaccompanied by other external shocks. The exception is Honduras, where agricultural production for domestic consumption suffers severely as a result of declining economic activity in export manufacturing, all of which translates into lower output. In this case, rural household consumption falls, government consumption expands only slightly, and the effect upon production discourages imports as compared to the scenario of trade policy reforms alone. Exports, particularly agricultural ones, are discouraged in all three countries and the trade deficit deteriorates. Production does not plummet in Costa Rica or El Salvador, however, as resources withdrawn from export sectors are promptly reallocated to nontradable production.

The favourable labour market effects of the trade policy reforms are offset by the external shocks, partially in Costa Rica and El Salvador, fully in Honduras. Both employment and wages decline in Honduras, particularly in tradable sectors. Total employment increases by less in Costa Rica than in the situation in which external shocks are absent, but wages end up rising because skilled workers are in greater demand in non-agricultural sectors. By contrast, there is new employment for workers of all types in non-tradable sectors in El Salvador, but the reduction in domestic prices brought about by the appreciating exchange rate lowers the average wage by comparison with the scenario in which external shocks are absent. Exchangerate appreciation also somewhat magnifies the effect of tariff reductions upon income distribution in the three countries, and generally cancels out the reduction of poverty recorded in Costa Rica and Honduras in the absence of external shocks. In contrast, poverty now diminishes somewhat in El Salvador as a result of the upsurge in non-tradable sectors.

RER appreciation has actually taken place in Honduras and El Salvador (figure 3) and, if the

\footnotetext{
${ }^{16}$ The exchange rate was assumed to be flexible (and foreign savings fixed) for this new simulation, even though the contrary had been assumed initially when simulating the trade policy reforms alone. In an experimental simulation using a flexible exchange rate that is not reported here, the trade policy reforms resulted in only a very marginal exchange-rate appreciation, and the resource allocation and income distribution and poverty effects remained essentially the same as when the exchange rate was assumed to be fixed (and foreign savings flexible).
}

simulation results are to be believed, this must have offset the expected effects of the trade policy reforms. El Salvador opted for a fixed exchange-rate regime in 1993 and dollarized its economy in 2001, during which time its RER appreciated substantially. It is unsurprising, therefore, that El Salvador has been transformed from an agro-export economy into a services economy (Segovia, 1998). Non-tradable sectors have driven economic growth in El Salvador, especially in the 1990s. In the case of Honduras, daily interventions in the currency market since 1994 have proved insufficient to prevent RER appreciation. The country's unimpressive economic performance has been underpinned by temporary increases in investment and government consumption since the 1990s (Cuesta and Sánchez, 2004). In Costa Rica, by contrast, a managed regime of periodic mini-devaluations of the local currency against the dollar has allowed a relatively stable and competitive real exchange rate to be maintained (figure 3). ${ }^{17}$ Thus, only in Costa Rica has exchange-rate policy proved consistent with the objectives of the trade policy reforms, since the country's mini-devaluations have helped to raise the relative profitability of exports.

Devaluation reinforces the effects of the trade policy reforms. The relative profitability of exports is found to rise sharply when the simulated trade policy reforms are combined with a $2.5 \%$ devaluation of the exchange rate (table 3$).{ }^{18}$ Exports increase significantly at the cost of lower investment in non-tradable sectors, but only in Costa Rica do they boost GDP substantially by comparison with the scenario of trade policy reforms alone (table 3). GDP falls in Honduras, not only because non-tradable production contracts but also because the devaluation increases production costs in a poorly diversified and unproductive export sector. Cuesta and Sánchez (2004) identify other CGE transmission mechanisms whereby devaluation has contractionary effects in Honduras.

The simulated devaluation reinforces the employment effect of the trade policy reforms in Costa Rica and El Salvador, as tradable sectors hire more workers, albeit at the cost of lower recruitment in non-tradable sectors. In Honduras, employment falls across all sectors as a result of the contractionary

\footnotetext{
${ }^{17}$ A new managed regime with upper and lower bands was put in place in Costa Rica in 2007.

18 This simulation was performed using the initial closure rule whereby the exchange rate is fixed and the current account with the rest of the world is balanced through foreign savings.
} 


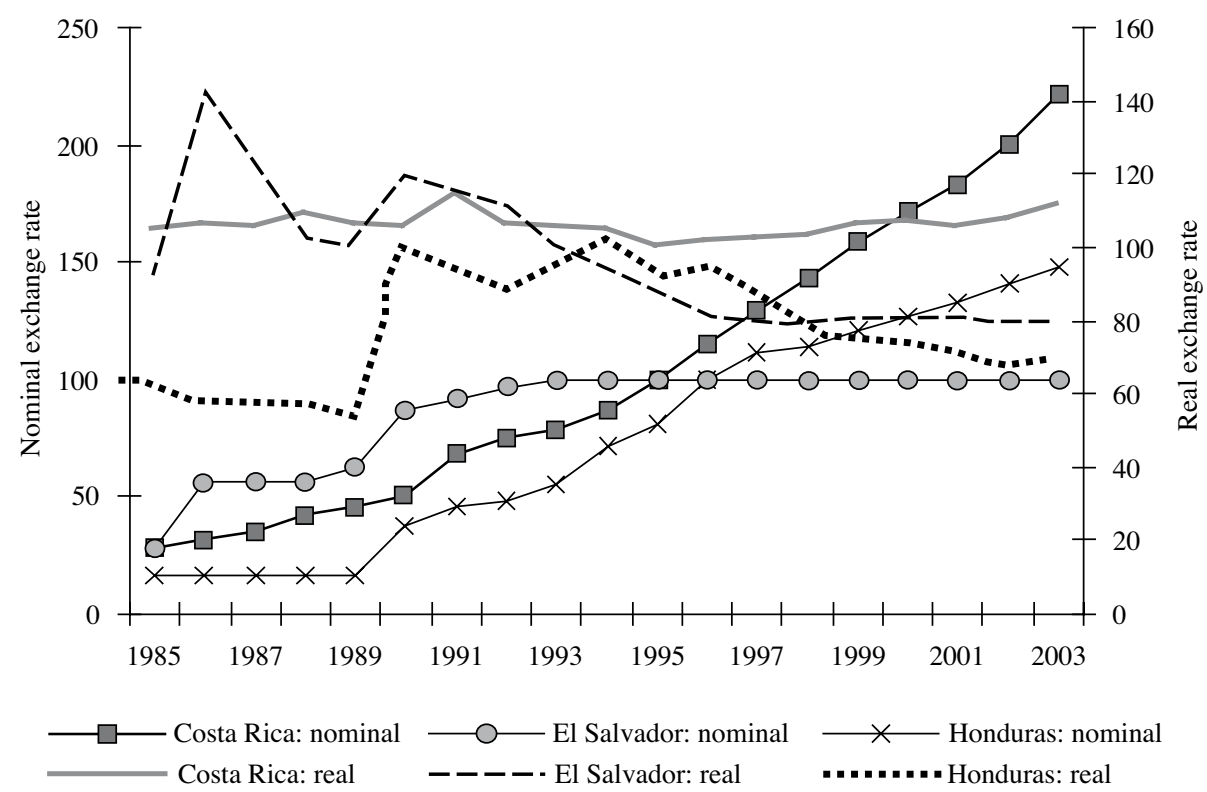

Source: Economic Commission for Latin America and the Caribbean (ECLAC).

effect of the devaluation. The devaluation pushes up domestic prices, leading to lower real wages in most cases. Nonetheless, the employment effect reinforces the poverty reduction observed in Costa Rica and El Salvador following the application of the trade policy reforms alone, although the effect is only marginal given that the prices of basic consumption goods and services rise. The poverty effect of devaluation is contrary to that of the trade policy reforms in Honduras on account of the contractionary effect referred to and the reduction of real wages. The disequalizing effect of the trade policy reforms is more than offset by the devaluation in Costa Rica and El Salvador, as the relative demand for skilled labour declines. In Honduras, the additional income distribution effect from devaluation as compared to trade policy reforms alone is virtually nil.

The simulation results and actual developments discussed so far indicate that only in Costa Rica has exchange-rate policy had the effect of reinforcing the benign effects of the trade policy reforms and offsetting the harmful effects of external shocks on export growth and poverty reduction. In the other two countries just the opposite has occurred, with exchange rate appreciation offsetting the effects of trade policy reforms on export growth and poverty.

\section{Trade policy reform and productivity}

The success of the trade policy reforms must also have been determined by the extent to which they have been accompanied by productivity growth. According to a decomposition of labour productivity changes presented in Sánchez (2005), Costa Rican workers became more productive in the economy generally during the 1990s and in agriculture, in particular, in 1990-2003. The same decomposition indicates that the evolution of labour productivity growth has been less satisfactory in El Salvador and Honduras, with the possible exception of El Salvador's industrial sector. Labour productivity has of course depended on the availability of human capital. The percentage of the economically active population aged 15 or over with more than 10 years of instruction is considerably higher in Costa Rica than in El Salvador and Honduras, particularly in rural areas, as it stood at $19.6 \%$ there around 2002, for example, compared with $8.9 \%$ and $4 \%$, respectively, in the other two countries (ECLAC, 2004). Imports of raw materials and capital goods have led to the absorption of improved technologies and better use of skilled labour in Costa Rica, even in agriculture (Sánchez, 2004). In El Salvador and Honduras, on the other hand, production in 
non-tradable sectors and in the maquila industry has been dominated by low-paid, low-skilled employment, hampering the achievement of sustained productivity growth through technological change.

Dynamic gains from trade are not endogenized in the CGE models, and total factor productivity (TFP) growth is exogenous. There is little empirical evidence regarding the drivers of trade-induced efficiency gains in the three countries. However, the final simulation in this paper is designed to achieve a better understanding of the effect of the trade policy reforms when accompanied by productivity growth. The trade policy reforms were also simulated in tandem with a productivity shock consisting of a $5 \%$ increase in TFP that is hypothetically driven by a matching 5\% increase in FDI and the relative supply of skilled labour.

The simulated productivity shock causes little variation in domestic prices but does give a remarkable boost to output, to which domestic absorption responds rapidly. On the whole, it reinforces the favourable allocative effects of the trade policy reforms and offsets the unfavourable ones (table 3). The modest employment growth that is triggered by the trade policy reforms alone becomes fairly substantial, especially in El Salvador and Honduras, where production dynamics lag farther behind. There is a much larger decline in poverty as a result, especially in Costa Rica, where extreme poverty falls dramatically. The reduction in poverty is far more modest in the other two countries, but the results and actual trends suggest that it is productivity and human capital shortfalls that have prevented those countries from experiencing poverty alleviation during the implementation of the trade policy reforms. There are also some undesirable effects from the productivity shock. Real wages decrease in Honduras as a result of a more atypical increase in the price of non-tradable goods (relative to exportables). In addition, the productivity shock magnifies the disequalizing effect of the simulated trade policy reforms in Costa Rica and El Salvador, something that does not happen in Honduras owing to the impact of labour force recomposition. This last result suggests that a reduction of income inequality in Honduras will necessarily require substantially increased human capital investment. By contrast, the relatively large and growing stock of skilled labour in Costa Rica has helped that country offset part of the negative distribution effects of the trade policy reforms and productivity growth.

\section{Conclusions and policy implications}

This paper's main conclusions have been drawn by combining simulation results from a computable general equilibrium model with actual data for the period 1990-2003. It has been found that trade policy reforms in Costa Rica, El Salvador and Honduras have unquestionably favoured the relative profitability of export sectors. Export-led growth and its trickle-down effects on the poor have been experienced only in Costa Rica, however, essentially for three reasons.

Firstly, Costa Rica's export sector has modernized and diversified to a remarkable degree, enabling the country to build up its capacity to generate foreign exchange and to absorb unfavourable price shocks more successfully. El Salvador and Honduras, on the other hand, have opted for greater specialization in maquila production, which adds little value to the economy owing to its extremely large import content.
Secondly, the inflows of remittances and private capital, and to a lesser extent the recurrent drops in world prices for key exports, have led to an appreciation of the real exchange rate in El Salvador and Honduras, offsetting the effect of the trade policy reforms on the relative profitability of export sectors. In Costa Rica, where remittances are less of a factor but inflows of private capital and FDI have exerted pressure on the real exchange rate, managed devaluations were successfully used to maintain a stable and competitive real exchange rate, and this has proved crucial when it comes to capitalizing upon the expected effects of the trade policy reforms.

Thirdly, Costa Rica has taken advantage of FDI and its increased capacity to generate foreign exchange in order to absorb technologies that, combined with a relatively large stock of skilled labour, have 
boosted labour productivity, even in agriculture. In El Salvador and Honduras, by contrast, a lack of dynamism in tradable sectors, very little diversification in agriculture and increased reliance on maquila production employing traditional technologies have all translated into higher demand for unskilled labour and low generation of value added.

Trade policy reforms have worsened the distribution of income in Costa Rica but poverty has fallen because the rural population, in particular, has benefited from stronger export growth. These trade policy reforms alone go only a little way towards explaining the poverty and income inequality trends observed in El Salvador and Honduras. Remittance inflows have unambiguously reduced poverty in those two countries, but income distribution has improved substantially only in El Salvador, where most recipients of remittances live in rural areas. In Honduras, by contrast, remittances mainly flow into urban areas, leaving the rural population relatively worse off.

Remittances have increased the consumption capacity of households in El Salvador and Honduras and have caused resources to be reallocated from tradable to non-tradable sectors, but they have barely boosted total production. This inertia in terms of production capacity and further appreciation of the real exchange rate may persist in the longer run, since remittances will probably continue to flow into these countries. This "remittance disease" may further constrain the creation of production capacity to generate employment over time, particularly in export sectors.

These conclusions call for policy action if these countries, especially El Salvador and Honduras, are to be able to increase the relative profitability of exports during trade liberalization under the aegis of CAFTADR and other trade agreements. Export diversification, technological change, human capital investment and productivity growth are preconditions for reaping the welfare gains from further trade liberalization. Export diversification, in particular, should be considered a priority because it reduces exposure to export price shocks that undermine the intended effects of trade liberalization. Policies will be needed to offset upward pressure on the real exchange rate from rising remittance inflows and the terms-of-trade deterioration that is expected to occur as demand for export goods and services declines in a slowing world economy marked by stubbornly high oil prices. The challenge will be to devise export promotion policies that are allowable under WTO rules and do not put public finances at risk. Costa Rica and Honduras can still resort to exchange-rate policy, but El Salvador cannot so long as its economy remains dollarized. The development of profitable remittance investment schemes will be crucial in countries like El Salvador and Honduras, particularly if such schemes are successful in boosting export production and employment.

(Original: English)
Acevedo, C. (2004), "El Salvador: efectos del crecimiento exportador sobre la pobreza y la distribución del ingreso", ¿Quién se beneficia del libre comercio? Promoción de exportaciones y pobreza en América Latina y el Caribe en los 90, E. Ganuza and others (eds.), Bogotá, D.C., United Nations Development Programme (UNDP)/AlfaOmega.

Almeida dos Reis, J.G. and R. Paes de Barros (1991), "Wage inequality and the distribution of education: a study of the evolution of regional differences in inequality in metropolitan Brazil", Journal of Development Economics, vol. 36, No. 1, Amsterdam, Elsevier.

Cox-Edwards, A. and S. Edwards (1994), "Labour market distortions and structural adjustment in developing countries", Labour Markets in an Era of Adjustment, S. Horton, R. Kanbur and D. Mazumdar (eds.), Washington, D.C., World Bank.

Cuesta, J. and M.V. Sánchez (2004), "Honduras: crecimiento exportador, distribución y pobreza”, ¿Quién se beneficia del libre comercio? Promoción de exportaciones y pobreza en América Latina y el Caribe en los 90, E. Ganuza and others (eds.), Bogotá, D.C., United Nations Development Programme (UNDP)/AlfaOmega.

Dervis, K., J. de Melo and S. Robinson (1982), General Equilibrium Models for Development Policy, Cambridge, Cambridge University Press.

ECLAC (Economic Commission for Latin America and the Caribbean) (2004), Social Panorama of Latin America 2002-2003 (LC/G.2209-P), Santiago, Chile. United Nations publication, Sales No. E.03.II.G.185.

(2006), Social Panorama of Latin America 2006 (LC/ G.2326-P), Santiago, Chile. United Nations publication, Sales No. E.06.II.G.133.

Edwards, S. (1988), "Terms of trade, tariffs, and labour market adjustment in developing countries", World Bank Economic Review, vol. 2, No. 2, Washington, D.C., World Bank.

Evans, H.D. (1989), Comparative Advantage and Growth: Trade and Development in Theory and Practice, Wheatsheaf, Brighton.

Ganuza, E., R. Paes de Barros and R. Vos (2002), "Labour market adjustment, poverty and inequality during liberalisation", 
Economic Liberalisation, Distribution and Poverty: Latin America in the 1990s, R. Vos, L. Taylor and R. Paes de Barros (eds.), Cheltenham, Edward Elgar.

Ganuza, E. and others (eds.) (2004), ¿Quién se beneficia del libre comercio? Promoción de exportaciones y pobreza en América Latina y el Caribe en los 90, Bogotá, D.C., United Nations Development Programme (UNDP)/AlfaOmega.

Löfgren, H., R. Lee and S. Robinson (2002), "A standard computable general equilibrium (CGE) model in GAMS", Microcomputers in Policy Research 5, Washington, D.C., International Food Policy Research Institute.

Robinson, S. (1989), "Multisector models", Handbook of Development Economics, H. Chenery and T.N Srinivasan (eds.), vol. 2, Amsterdam, Elsevier.

Salvatore, D. (1995), International Economics, New York, PrenticeHall.

Sánchez, M.V. (2004), Rising Inequality and Falling Poverty in Costa Rica's Agriculture during Trade Reform. A Macromicro General Equilibrium Analysis, Maastricht, Shaker.

(2005), "Reformas económicas, régimen cambiario y choques externos: efectos en el desarrollo económico, la desigualdad y la pobreza en Costa Rica, El Salvador y Honduras", Estudios y perspectivas series, No. 36 (LC/
L.2370-P), Mexico City, ECLAC Subregional Headquarters in Mexico. United Nations publication, Sales No. S.05.II.G.111. (2007), "Liberalización comercial en el marco del DRCAFTA: efectos en el crecimiento, la pobreza y la desigualdad en Costa Rica", serie Estudios y perspectivas, No. 80 (LC/ MEX/L.771/Rev.1), Mexico City, ECLAC Subregional Headquarters in Mexico. United Nations publication, Sales No. S.07.II.G.48.

Sánchez, M.V. and P. Sauma (2006), "Costa Rica - exportorientation and its effect on growth, inequality and poverty", Who Gains from Free Trade? Export-led growth, inequality and poverty in Latin America, R. Vos and others (eds.), New York, Routledge.

Segovia, A. (1998), "Cambio estructural, políticas macroeconómicas y pobreza en El Salvador", Politica macroeconómica y pobreza en América Latina y el Caribe, E. Ganuza, L. Taylor y S. Morley (eds.), Madrid, Mundi Press.

Vos, R. and others (eds.) (2006), Who Gains from Free Trade? Export-led Growth, Inequality and Poverty in Latin America, New York, Routledge.

Wood, A. (1994), North-South Trade, Employment and Inequality: Changing Fortunes in a Skill-Driven World, Oxford, Clarendon Press. 